\title{
F.L.ライトの『リヴィング・シティ』にみられる R.W.エマソンの農業思想の影響に関する研究 A STUDY ON INFLUENCE OF RALPH WALDO EMERSON'S AGRARIAN THOUGHTS ON "THE LIVING CITY" BY FRANK LLOYD WRIGHT
}

\author{
竹内孝治*，小川英明** \\ Kohji TAKEUCHI and Hideaki OGAWA
}

\begin{abstract}
The aim of this paper is to evaluate an philosophy of city planning by Frank Lloyd Wright (1867-1959), a famous architect, in the context of modern American city planning by specifically scrutinizing his discourses on 'The Living City' (1958) where the Broadacre City was proposed, and to identify philosophical influence of Ralph Waldo Emerson (1803-1882), a famous philosopher, on agrarian thought of Wright.

After collecting exhaustively Wright's discourses on agriculture and the Broadacre City together with Emerson's discourses on agriculture, we categorized and compared them to clarify any similarity and difference. We concluded that the Wright's agrarian thoughts have strong influence from Emerson's agrarian thoughts in the context of transcendentalism, and Wright designed his ideal city where farmers have genuine lives in the form of Broadacre City.
\end{abstract}

Keywords: Frank Lloyd Wright, Ralph Waldo Emerson, Transcendentalism, Agriculture, The Living City フランク・ロイド・ライト, ラルフ・ウォルド・エマソン, 超越主義, 農業, リヴィング・シティ

\section{1.はじめに}

本研究は、19世紀アメリカにおいて広範な影響力をもったとさ れる超越主義(Transcendentalism)の思想が、アメリカ近代の建築 · 都市の形成に果たした影響関係を分析し、その歴史的意義を考究す る研究の端緒として、建築家フランク・ロイド・ライト Frank Lloyd Wright:1867-1959)の理想都市「ブロードエーカー・シティ」 の根幹をなす農業思想と超越主義の代表的思想家ラルフ・ウォルド ・エマソン(Ralph Waldo Emerson:1803-1882)の農業思想との影響関 係を考察することを目的としたものである。

超越主義はニューイングランド地方でのキリスト教ユニテリアン 派に出自をもつが、その思想は宗教の枠を超え、アメリカの個人や 社会の主体性を鼓舞し、奨励したものと評されている。超越主義思 想は宗教、文学、美術の分野にとどまらず、建築や都市の思想にも 少なからず影響を与えたことが幾多の文献で指摘され、その射程は 機能主義的思想の先鞭をつけた H.グリーノー (Horatio Greenough:1805-1852)から、「有機的建築」を提唱したライト、文明 評論家L.マンフォード(Lewis Mumford:1895-1980)にまで及ぶ。超越 主義（者）がアメリカ近代建築・都市の形成に及ぼした影響を頻繁 に言及する多くの著作では、とりわけエマソンの思想がライトに多 大な影響を与えたことが指摘されている。
実際、ライトは彼の都市論の集大成として位置づけられる『リヴ イング・シティ(The Living City)』(1958) ${ }^{11}$ の巻末に、「ラルフ・ウ オルド・エマソンの農業についての随筆より(From Ralph Waldo Emerson's Essay on FARMING)」 ${ }^{2)}$ を附録として収録している。後 述するように、このような特定の思想家の特定の言説をまとまった 分量で自著に引用することは極めて特異であり、ライトはエマソン を明確に意識し、この引用に特別な意味を込めていたと思われる。 周知のように『リヴィング・シティ』は、1932 年の『消えゆく都 市(The Disappearing City)』(1932) ${ }^{31}$ から『民主主義建設の時(When Democracy Builds)』(1945) (これら 3 著作を以下では都市関連 3 著作 ${ }^{5)}$ と記す）を経て発展させられてきたもので、そこでは農業的 色彩の極めて強い都市モデルが提案されている。これら都市関連 3 著作ではエマソンをはじめとする超越主義思想家について頻繁に言 及しながらも、ブロードェーカー・シティにおける農業思想の源泉 には一切触れておらず、唐突にエマソンの随筆「農業」を引用した わけである。

本稿は、こうしたライトによるエマソンの随筆引用に着目し、ラ イトの都市論『リヴィング・シティ』において重要な位置を占める 農業思想が、エマソンの超越主義に基づく農業思想からの強い影響 のもとに形成されたことを論ずる。

\footnotetext{
* 愛知産業大学造形学建築学科 非常勤助手 $\cdot$ 修士 (建築学)

** 愛知产業大学大学院造形学研究科 教授 $\cdot P h . D$.
}

Research Assist., Dept. of Architecture, Faculty of Architecture and Design, Aichi Sangyo Univ., M. Arch.

Prof., Dept. of Architecture, Graduate School of Architecture and Design, Aichi Sangyo Univ., Ph. D. 


\section{2. 既往研究と本研究の位置づけ}

ライトの理想都市「ブロードエーカー・シティ」に関する既往研 究としては、Alofsin ${ }^{6)}$ 、Fishman ${ }^{7}$ 、水上 ${ }^{8)}$ 等の研究がある。Alofsin や Fishman は毁誉褒貶半ばするライトの都市論に対する史的評価の 変遷を整理しつつ、都市計画上の妥当性や後世への影響等の評価に 偏重することなく、そこにみられる思想が持つ可能性を再評価する 必要性を説いている。また水上は近年におけるライトの都市に関す る研究が、具体案の検証から背後にある思想の検郡へと向かってい ることを指摘するとともに、ライトの言説にみられる都市論を読み 解き、具体案の持つ意味を考究している。これら諸研究の動向は、 総じてライトのブロードエーカー・シティがもつ思想的背景を探る 必要性を指摘するものといえる。

また、本稿が考究するライトの思想への超越主義者エマソンの影 響に関する研究としては、クロノン ${ }^{91}$ 、水上 ${ }^{10)} 、$ Uechi ${ }^{111}$ 、大倉 . 鈴木 ${ }^{21}$ らによる論考が充実した内容として認められる。クロノン はライトへのエマソンの多大な影響を指摘するとともに、その淵源 に母親のエマソン崇拝を挙げ、ライトの“自然”や“有機”等の主 要概念を読解するにはエマソンの思想が必要不可欠であると言及し ている。水上はライトの言説からエマソンのほかソロー(Henry David Thoreau:1817-1862)、ホイットマン(Walt Whitman:1819-1892)に 対しても各人の思想を整理した上で、ライトの思想との相同性を考 察している。Uechi はライトへのエマソンの影響を、ライトの実作 品であるユニティ教会(Unity Temple:1906)を例に考察している。大 倉・鈴木はエマソンの造形思想を整理・考察する過程で、ライトへ の影響について言及している。

これら諸研究の他に、ライトの都市論を彼の農業思想を軸として 考究したものとして Ciucci ${ }^{13)}$ が挙げられる。Ciucci はトマス・ジ エファーソン(Thomas Jefferson:1743-1826)との関連からライトの農 業思想に触れ、ジェファーソンらの反都市思想、農業主義思想が色

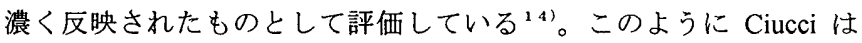
ライトの都市論を特に農業主義者(Agrarian)の視点から考察し、ラ イトの数多ある言説から特に農業思想に着目したものとして本研究 への重要な示唆として特筆できる。しかし、Cuicci はエマソンを、 ジェファーソン、ホイットマン、ソロー、T.カーライル(Thomas Carlyle:1795-1881)等とともにライトの都市論において評価される思 想家として位置づけてはいるものの、その具体的影響については詳 らかにしていない。

以上にみた研究は、エマソンがライトへ及ぼした影響を、彼の個 々の言説や特定の建築作品をもとに考究するものとして、本研究に おいて重要な既往研究とみなせる。しかしながら、ライトの都市論 にみられる色濃い農業主義の実相や、エマソンの随筆引用がもつ意 味を論じ、それらをライトの都市論と架橋し歴史的評価を試みるも のは未だみられない。このような先行研究をふまえ、本稿は、ライ トの言説にみられる農業思想とエマソンの農業思想との比較・分析 により、諸論評によってなされる影響指摘の妥当性および認められ る影響の内容・程度を、農業という側面から検証し、『リヴィング ・シティ』の巻末に引用されたエマソンの随筆の意味を考究するも ので、これまでの諸論評において指摘されながらも明確に示されて こなかった両者の影響関係を具体的に明らかにすることを試みるも のである。
3.ライトの言説にみられる人物言及と随筆引用

ライトとエマソンそれぞれの農業思想を分析するに先立ち、ライ トの言説にみられる人物言及について概観し、エマソンの随筆「農 業」の引用が持つ特異性・重要性を確認しておく。

3.1 ライトの言説にみられる超越主義者への言及

ライトの言説には建築家、思想家、芸術家、宗教家、政治家等、 古今東西の多岐にわたる人名をみることができる ${ }^{15)}$ 。建築設計の 師 L.H.サリヴァン(Louis Henry Sullivan:1856-1924)の 140 箇所やD.ア ドラー(Dankmar Adler: 1844-1900)の 37 箇所をはじめ、妻のオルギ ヴァンナが 73 箇所といったように、知人や縁故者らの人物言及が 特に多くみられる。次いで、大統領 T.ジェファーソンが 34 箇所、 建築家H.H.リチャードソン(Henry Hobson Richardson:1838 -1886)が 24 箇所等のように、ライトが尊敬・敬愛した人物への言及が数多 くなされている。こうした人物群に加え、超越主義者についての言 及も延心゙ 60 箇所と際だって多い ${ }^{16)}$ 。内訳はエマソンが 18 箇所、 ソローが 12 箇所、ホイットマンが 28 箇所、その他 2 箇所で、エマ ソンへの言及が際だって多い訳ではないが、『リヴィング・シティ』 においては、T.ジェファーソン、老子、キリストとともにェマソ ンが最も多く言及されている。

3.2 ライトによるエマソンの随筆引用

言及人物の著した文章自体をライトが引用したものとしては、本 稿で扱うエマソンの随筆の他にも、超越主義者ホイットマンやソロ —17)、詩人A.L.テニスン(Alfred Lord Tennyson:1809-1892)の詩編、 W.ブレイク(William Brake:1757-1827)の筬言等々があるものの ${ }^{18)}$ 、 エマソンの随筆のようにまとまった分量の言説を何ら説明もなく唐 突に引用している例は他にはみられない。

ライトが自著巻末に引用したエマソンの随筆は、講演集『社会と 孤独(Society and solitude)』(1870)に収録された「農業(Farming)」の 一部であり ${ }^{19) 、}$ 処女出版である『自然(Nature)』(1836)から、生前 最後の出版となった『書簡および社会論(Letters and Social Aims)』 (1875)に至る彼の著述生活の最晚年に位置するものである。

ライトは引用にあたって『リヴィング・シティ』本文中で言明す る論旨と重複する随筆「農業」の文章について中略を施し、元来は 全 3852 語からなる文章のうち 1631 語を拔粋している。特にエマソ ンが好んで言及する化学や地学など自然科学の語番を用いた比喻が 含まれる箇所は往々にして省かれ、ライト自身が『リヴィング・シ ティ』本編において触れる経済や土地所有に関する言及も総じて除 外されていることが指摘できる ${ }^{20 !}$ 。また、イギリスやコンコード 等特定の土地を事例として挙げる内容も同様に省略されている。

このように自著巻末附録としての随筆引用、そして収録に際して の中略・編集という事実からも、エマソンの随筆「農業」は、ライ トがエマソンの思想に対していかなる付置を構成したかを考察する 好個の対象と考えるに充分なものと認められよう。

\section{4.エマソンの農業思想}

前述したように、農業・農村に重点を置いた都市像を描く『リヴ ィング・シティ』の巻末付録としてェマソンの随筆が引用されてい ることをうけて、ライトとエマソン両者の間にみられる思想の相同 性・相異性を見極めるために、まずエマソンの農業思想を明らかに する ${ }^{211}$ 。 


\section{1 エマソンの言説にみられる農業関連言説}

彼の代表的著作を網羅的に収録する『R.W.エマソン全集(The Complete Works of Ralph Waldo Emerson)』 ${ }^{22)}$ (著書 8 冊計 98 編、 詩編 163 編、講演・伝記 19 編に書簡、雑纂を収録) を対象として、 農業に関連する語句 ${ }^{23)}$ を含んだ言説（以下、農業関連言説と記す） を抽出・考察した。その結果、エマソンの農業関連言説は随筆「農 業」以外にも数多くみられ、「コンコードでの歴史的言説(Historical Discourse at Concord)」(1835)から、『自然』所収の「訓練(Discipline)」 (1836)、『社会と孤独』所収の「文明(Civilization)」(1870)まで、全 16 編において論じられている。

これら農業関連言説には、“都市は常に、田舎によって元気をと り戻す(The city is always recruited from the country)"[CWE 7:140]とい った表現に端的に表される農村・農夫／都市・都会人といった二項 対立的論理構造を見出すことができ、基本的に田舎や自然への肯定 的態度と反都市的姿勢が貫かれている。こうした志向性をもつエマ ソンの農業関連言説における思想表明・洒值判断について、収集し た言説にみられる主題別に分類・整理した結果 ${ }^{24}$ 、〈自然＝神性と の調和〉、〈自己修養・訓練〉、〈国土の美化効用〉の 3 つに大別さ れた ${ }^{25)}$ 。これら $3 つ の$ 農業関連主題について、その言及内容を以 下のように要約できる。

〈自然二神性との調和〉

エマソンの農業思想は、その根幹にまず自然に対する賛美があり、 それとの交感を基底にしてあらゆる洒值判断が派生している。自然 に近接する職能である農業を最も古く普遍的かつ真正な職能として 位置づけている。

- - every natural process is a version of a moral sentence. $\cdot$

- What is a farm but a mute gospel? The chaff and the wheat, weeds and plants, blight, rain, insects, sun, - it is a sacred emblem from the first furrow of spring to the last stack which the snow of winter overtakes in the fields. [CWE 1:41-42]

・・自然のあらゆる過程は、道德を表した文章の翻訳である。

・・・農業は無言の福音でなくて何であろう。もみがらと小麦、 雑草と草木、害虫、雨、昆虫、太陽一これは春に最初の㑼がつく られる時から、冬に最後の乾草が積まれ、これに雪が積もる頃ま での一年を通じて、聖なる象徴である。

自然を聖なるものの顕現として捉え、そこへと近接することに徳を 見出す姿势は、エマソンだけでなく、超越主義者に総じて見出せる 思想基底といえるが、エマソンはさらにこれを敷衍したかたちで農 業を肯定的に評価している。

\section{〈自己修養・訓練〉}

農業に従事することで正常な心性が育まれるといった自己の修盖 ・訓練の効用を説く言説は、随筆「改革者としての人間」(1849)に みられる。

In general one may say that the husbandman's is the oldest and most universal profession, and that where a man does work more than another, this may be preferred. • - • that labor is God's education; that he only is a sincere learner, he only can become a master, who leans the secrets of labor, and who by real cunning extorts from nature its sceptre. [CWE 1:240-241]

農夫の職業はもっとも古く、同時にもっとも普遍的な職業であ
り、人がある特定の仕事に対する適応性を自己のうちに発見しな い場合には、この職業を選ぶのがよいであろう。・・・労働は神 による教育であり、労働の秘訣を学んで、真の技巧によって自然 から支配権を取り立てる人だけが支配者になりうるというのが、 その教義である。

さきにみた〈自然＝神性との調和〉を体現する農夫は、神の顕現と しての自然とより強く、より良く調和するゆえに、ここでみるよう な自己修練・訓練がなされるものとして評価されることとなる。 〈国土の美化効用〉

土地利用や食糧の確保といった面だけでなく、勤労や工夫、わが 家に対する愛情などの特性から、農業の美点を人々の生活から国土 の美化にまで及ぶものとして位置づけている。

For beside all the moral benefit which we may expect from the farmer's profession, when a man enters it considerately; this promised the conquering of the soil, plenty, and beyond this the adorning of the country with every advantage and ornament which labor, ingenuity, and affection for a man's home could suggest. [CWE 1:366]

農夫の職業に期待できる道徳上の利益別として、人が慎重な 態度でこの職業に就くとき、それは土地の征服と豊作とを約束す るばかりでなく、勤労、工夫、わが家に対する愛情などから連想 されるあらゆる美点と装飾とをもって国土を美化することを約束 する。

以上のようにエマソンの農業思想は、農業が神性の顕現としての自 然に近接し、農夫は人間性・道徳性を訓育されるとするなど、全肯 定的な評価のもとに位置づけるものといえる。

\section{2 随筆「農業」にみられる農業思想}

ここにみたエマソンの農業関連言説にみられる 3 主題は、彼の著 作の中で各々別個に触れられているが、晚年の随筆「農業」では、 それらが十全に語られている。たとえば、〈自然＝神性との調和〉 は以下のような言明に窥える。

The farmer times himself to Nature, and acquires that livelong patience which belongs to her. [CWE 7:139]

農夫は大自然に調和し、自然のものである長い忍耐力を身につ ける。

また、〈自己修養・訓練〉については次のように触れている。

The lesson one learns in fishing, yachting, hunting or. planting is the manners of Nature; patience with the delays of wind and sun, delays of the seasons, bad weather, excess or lack of water, - patience with the slowness of our feet, with the parsimony of our strength, with the largeness of sea and land we must traverse, etc. [CWE:139]

釣りや船遊び、漁や植え付けをすることで学ぶところの一つの 教訓は、すなわち自然の作法を知ることにある。風や陽、四季、 悪天候、水の過不足の遅延を忍び、われわれが渡らねばならない 海や陸の偉大さを、ゆっくりした足取りで、倹約する力でもって 耐え忍ぶこと等がそれである。

こうした農夫の高い人間性・精神性ゆえに、“都会の道徳上および 知識上の健康と活力が出てくるのは、すべて彼からである (it is from him that the health and power, moral and intellectual, of the cities came)" [CWE 7:140]とエマソンは説き、農夫がもつ自己修養の効 用と、それによりもたらされた高い人間性を評価している。 
そして、〈国土の美化効用〉については以下のように言明する。

$\mathrm{He}$ is the continuous benefactor. He who digs a well, constructs a stone fountain, plants a grove of trees by the roadside, plants an orchard, builds a durable house, reclaims a swamp, or so much as puts a stone seat by the wayside, makes the land so far lovely and desirable.

[CWE 7:141]

農夫はいつも恩恵を与える。また果樹園を作り、丈夫な家を建 て、沼地を開墾し道端に石座を設けたりする。これらは国土をは るかに美しいもの、望ましいものにする。

このように、随筆「農業」は、エマソンの農業思想の軸をなす $3 つ$ の主題が須く言及されており、エマソンの農業思想が十全に開陳さ れたものとして位置づけられる ${ }^{26)}$

\section{5. ライトの農業思想}

次に、『リヴィング・シティ』を対象に、ライトの農業関連言説 を抽出・分析し、そこにみられる農業思想とその変遷について考察 する。

\section{1 計画案にみられる農業関連諸施設}

言説分析に先立ち、ブロードエーカー・シティの計画案にみられ る農業関連諸施設の計画・デザインについて整理しておく。

『リヴィング・シティ』に収められた図版計 55 枚のうち、提案 される図面・模型写真は 52 枚、そのうち 7 枚が “農民住宅 (farm building)”あるいは “小農園のための典型的な住宅 (typical dwelling for little farms)” といった農業関連施設に関するものである。低密 度で水平に拡がるブロードェーカー・シティは、都市よりは農村に 近い人口密度で構想され、そこに小農園、葡萄園および果樹園、農 業研究施設、林間小屋といった諸施設が配置される。農業施設群は プレファブ・ユニットを組み合わせて造られ、スーパーマーケット とはハイウェイ交通で結ばれる。こうした諸施設をライトは以下の ように説明する。

It is true functioning on the broad basis of any democratic economy radical to our vast gift of magnificent ground. [LC:163]

わが国の広大な土地の非常に豊かな産物に根ざした、民主的経 済全般にわたる極めて幅広い基盤に立った本来的機能といえる。 ライトはこうした空間デザインによって「有機的な“農耕救済” (organic "farm relief")」が可能となり、さらには「都市の解放 (urban release)」をもたらすとした[LC:163]。

そして、これらの農業関連施設が“隣接する他の農園や産業や文 化に本当にしっくりとつながり、また諸君の村のなかでの諸君の生 活と結びつき、互いによく釣り合いを保ち、具合良く地取りされて いる (true relation to adjoining farms and industry and culture, to you in your villages and all related to our national economy.)”ことで、ブロ 一ドエーカー・シティの住民たちは “全て一つの偉大なドラマティ ックな全体 (multiple parts all thus contributing to a great dramatic) "に 貢献する生活を営むことになる。それは “諸君がどこから眺めても 全体の眺めは真に美的な、幻想的な人生であろう（the life of the imagination truly aesthetic, in the over-all view from wherever you may happen - to stand)" と論じている[LC:93]。以上のことからも、ライ トの都市構想においては農業が極めて重要な位置を占めていたこと がわかる ${ }^{271}$

\section{2 ライトの言説にみられる農業思想}

さきにみたエマソンと同様にライトの農業関連言説を分類・整理 した結果、大別して〈農業が支える都市生活〉、〈農夫の民主的人 間性〉、〈国家の農耕文化〉について論が展開されている。これら 主題別にみて、彼の農業思想が持つ特質を以下のように要約するこ とができる。

\section{〈農業が支える都市生活〉}

大地から食糧を生産・供給する農業の基本的役割を指摘し、さら にそこに人閒と土地と資本の良好な関係の成立を認めることで、あ るべき農業を基礎とした理想的都市生活を志向する。

But in the new city will go out to service him as he services the city, the citizen not merely there to be fed but to share in the common luxury which the very nature of the farmer's intrinsic service to society has now made possible $\cdot$. . Society will share indigenous culture with the farmer. His establishment is now most welcome to all as a fine feature of the city. [LC:160]

しかし、新たな都市は、彼に正当な位置と分配を与える。新し い都市は、彼らが都市に尽くすように彼らに奉仕し、市民はただ 単に食べさせてもらうためだけに都市に住んでいるのではなく、 農民の社会に対する内在的奉仕の性格が、いまや可能にした大衆 の贅沢を分け合うのである・・・。社会はその土地の文化を農民 と分け合い、農民の事業は都市の立派な性格として、いまや全て の人々に非常に歓迎されるであろう。

〈農夫の民主的人間性〉

高い人間性をその属性として備える農耕に対し、産業が望ましい かたちで両立することで、“有機的民主主義 (Democracy organic)” [LC:132]を育み、それが、“正真正銘のアメリカ文化（genuine American culture)”[LC:162]を営むことができるとする。

We are by nature gifted as a vast agronomy. In the humane proportion of those two - industrialism and agronomy - we will produce the culture that belongs to Democracy organic. [ LC:222]

われわれは生まれながらに広大な農耕を授けられている。これ ら二つのもの一産業と農耕一の人間的なプロポーションの中にわ れわれは有機的民主主義のものである文化を生み出すことができ る。

\section{〈国家の農耕文化〉}

農業を来るべき民主的都市におおる主要な業態として評価すると ともに、アメリカ国家の文化基盤として位置づける。そして、それ がライトの都市論における重要概念 “ユーソニア”の何たるかを知 る主要な鍵であると言明する。

- - you will get a glimpse of the country-loving life in agronomy of the new Usonian city, belonging by nature to the national agronomy of the vast nation our forefathers had some right to expect would come of what they were pleased to call Freedom. Then only will you see Usonia. [LC:93]

・・・もし諸君がこれらすべてを看取することができるなら ば、諸君はユーソニアの新しい都市での農耕生活の中に、愛国的 な人生の閃光をよみとることであろう。そしてそれは当然、わが 国の民主的将来の国家的農耕に属するものである。われわれの祖 先たちが当然期待していた、そして彼らがそれを自由と呼ぶのを 
快しとした広大な国家の農耕文化が訪れよう。そうなってこそ初 めて諸君はユーソニアの何たるかを知るであるう。

このように、ライトの農業思想は当時の社会において分断された人 間と土地と資本の良好な関係を回復するものとして農業を再評価す るとともに、彼の建筑・都市論において重要な概念であるユーソニ アへと至る有機的な民主主義文化を生み出す核として位置づけてい る。また、かつての農耕社会の懐古的希求ではなく、現代的な産業 と一体となることを今日望まれる社会形態であると位置づけた点に ライトの農業思想の特質が認められる。

\section{3 都市関連3著作にみられる農業関連言説}

さきに『リヴィング・シティ』を対象としてみたライトの農業思 想が、都市関連 3 著作を通していかなる変遷を辿ったかを、言及主 題別に考察する。

都市関連 3 著作は理想都市ブロードエーカー・シティの計画構想 を開陳することを主たる目的とすることは同様ながら、その都度の 知見を盛り込み、体裁・書名も変更を加え分量も増加している。ま た、その内容からは同一の章立て、記述を含みながら発展的に改訂 されてきたことを確認できる。そのなかで特に注目に值するのは、 農業に関して多くの言及がみられる『リヴィング・シティ』の「ユ ーソニアの農民(The Usonian Farmer)」[LC:158-160]および「巨大 な口 (The Great Mouth)」[LC:160-164]の各節である。前著『民主主 義建設の時』においてはこの 2 つの節を一括して「ユーソニアの農 園 (The Usonian Farm)」 [WDB:92] と題し収録していたものであり、 さらに遡って『消えゆく都市』においては「土地の耕墾者、そして 家畜の管理人(The Tiller of Soil and the Husband of the Animals) 」 [DC:64]のなかで触れられていたものである。

3著作における各主題への言及傾向に着眼し、その内容を整理し た結果、ライトの農業思想にみられる変遷過程を以下のように要約 できる。

\section{〈農業が支える都市生活〉}

大地に接して労働し、大地から食糧を得ることにより都市を支え るという農業の機能、農夫の職能については、都市生活者との対比 の中で語られ、都市は「巨大な口(The Great Mouth)」と表現される。 こうした言及は既に『消えゆく都市』において「農夫は基本的に人 々の食糧である。都市を養うことが彼の仕事である。そして衣服の ための素材もまた彼の仕事なのである。（The farmer is essentially food for humanity. It is his job to feed the cities. And the raw material for clothing is his job also.)」[DC:64]として語られており、また、『民主 主義建設の時』においても同様の表現をみることができる [WDB:92]。

さらに『リヴィング・シティ』では、前述したように節の見出し として「巨大な口」が扱われるようになり、その記述の内容・量と もに増加している[LC:160]。

\section{〈農夫の民主的人間性〉}

当初、『消えゆく都市』では反都市的な言明のもとに、虐げられ た農夫を救済されるべき対象として言及しているが、農夫の人間性 に関してはわずかに次のような言及がみられるに過ぎない。

- Parasites are parasites because they batten upon sources, live upon origins but never live by originating. So here in the tiller of the soil is good life, and genuine, in deep trouble. [DC:64]
・.・彼らは資源の上に栄え、資源の上に生活するけれども、 始原の創出によっては生活していないからこそ、寄生者は寄生者 に過ぎない。だからここでは、農夫は良き純粋な生活が大きな問 題を抱えているのだ。

『民主主義建設の時』や『リヴィング・シティ』においては、解 放された農夫・農業の姿に触れつつ、「わが国の農園や農村からも う一度新しく出直さなければならない (it must renew itself from our farms and villages.)」[LC:68] と説き、人閒性の涵養に向けて、次の ような肯定的表現で語られるようになる。

Of all the underlying forces working toward emancipation of the city dweller, most important is the gradual reawakening of the primitive instincts of the agrarian. [LC:62]

都市に住む者たちの解放に対し働きかけている、様々な底流の なかで最も大切なものは、農耕という原始的本能が再び徐々にで はあるが目覚めつつあるということである。

〈国家としての農耕文化〉

農業により達成される真正なアメリカ国家の文化形成について語 り、さらにはその理想的民主社会を指す上位概念 “ューソニア”と 併せて触れる記述は、『消えゆく都市』には見出されない。次いで、

『民主主義建設の時』においては「ユーソニアの農園（The Usonian Farm)」[WDB:92]といった節の見出し、あるいは提案する農場に ついての「根本的な民主主義的社会の広範なる基礎における真正な 礎石である。（It is the true cornerstone in the broad basis of any radical, democracy society.)」[WDB:96] といった表現、さらには「あとが (Looking Backward)」[WDB:140]の中で簡単に触れられる程度であ ったが、『リヴィング・シティ』においては、先に触れた「諸君は ユーソニアの新しい都市での農耕生活の中に、愛国的な人生の閃光 をよみとることであるう (you will get a glimpse of the country-loving life in agronomy of the new Usonian city)」[LC:93]といった表現にみ られるように積極的に語られるようになる。

以上、都市関連 3 著作における農業関連言説を見る限りに㧤いて、 農業を軸としたライトの都市論は 3 著作が発表された時系列に沿っ て段階的に農業に関する言及が発展・拡充していったことが指摘で き、特にライトが農業について言及する主題を最も十全かつ豊富に 記述するのは『リヴィング・・シティ』であるといえる。こうした段 階的な農業の重視傾向、特に農業という職能に対して高い人間性を 見出し、ユーソニアにおける重要性を打ち出す姿勢の高まりは、巻 末附録としてそれまでの 2 著には無かったエマソンの随筆引用と強 い関連があることが窥われる。

\section{6. ライトとエマソンの言説にみられる農業思想の比較分析}

これまでにみたライトおよびェマソンの農業思想を主題別に比較 ・考察した結果、相同性および差異性を以下のようにまとめること ができる。

(1)ライトの〈農夫の民主的人間性〉は、まさに農業が自然との調和 のもとに行わ机る生業であることに依拠する。〈自然＝神性との調 和〉を謳うェマソンの農業思想にも、ライトと同様に自然から遠の いた都市生活が、基本的には人間の活力を消耗させるものであり、 ひとびとは農村・田舎へ還るべきと主張されている。ライトはこう した都市と農村の関係を次のように語っている。 
But not one of our big cities can subsist long on its own birthrate as birthright; therefore, a vampire, it must renew itself from our farms and villages. [LC:68]

しかし、都市自体の出生権としての出生率の上に、そう長らく 生命を保つことのできるような都市は、わが国に一つとして見当 たらない。であるから、この吸血鬼はそれ自体、わが国の農園や 農村からもう一度新しく出直さなければなるまい。

こうしたライトの言説と極めて似通った言明をエマソンは以下のよ うに行っている。

Poisoned by town life and town vices, the sufferer resolves; 'Well, my children, whom I have injured, shall go back to the land, to be recruited and cured by that which should have been my nursery. . .'

[CWE 7:134]

都会生活と、都市の悪徳によって害され、犠牲者はこう決心す る。“私が傷つけた子どもたちよ、さあ、田舎へ戻ろう。そこで 治療を受けて回復するために・・”。

(2)〈農業が支える都市生活〉で語られる自然・大地から直に糧を得 る高貴な姿勢は、エマソンの〈自己修養・訓練〉に関する主題にも 見出される。農夫は自然・大地に近接し労働する過程で自己の修盖 ・訓練がなされ、そこで育まれた徳が人々の生活へ恩恵としてもた らされる。こうした言明は両者ともに極めて類似した表現をなして おり、例えばそれは都市の食糧を司る業態として農業を位置づける 以下のようなライトの姿勢において顕著である。

Cities are huge mouths. Essentially the farmer is foodmaster for the great mouth. He has many subsidiaries, but his primary job is to feed these great feudal survivals of the city. - - Without the farmer our towns and cities, big and small, would go naked and starve. [LC:160]

都市は極めて巨大な口である。農民は本来この巨大な口のため に、食糧を司る主人である。彼らは多くの従属的な仕事をもつが、 彼らの第一の仕事はこれら多くの、そして大きな封建的遺物であ る都市に、食糧を与え育て上げることである。・・農民がいな ければ、わが国の都市や町村は、大きいものも小さいものも、裸 で震え、飢えに苦しむであろう。

同様の志向性がみられるエマソンの言説例として、以下がある。

$\mathrm{He}$ has grave trusts confided to him. In the great household of Nature, the farmer stands at the door of the bread-room, and weights to each his loaf. - . The farmer is a hoarded capital of health, as the farm is the capital of wealth; and it is from him that the health and power, moral and intellectual, of the cities came. The city is always recruited from the country. [CWE 7:136]

農夫は自分に任された重要な役目をもっている。自然という大 所帯のなかで、農夫は食糧室の入口に立ち、それぞれに彼の食糧 を計る。・・あたかも田園が富の資本であるように、農夫は健 康の蓄積された資本であって、都会の道徳上ならびに知識上の健 康と活力の源は全て農夫からのものである。都市は常に田舎によ って元気を取り戻すのだ。

(3)エマソンにおいては主題として言及されていた〈国土の美化効用〉 について、ライトの〈国家としての農耕文化〉では、そこに止まら ずに、農業を主体とした都市こそが有機的な民主主義の文化を育む “ユーソニア”と位置づけている。これは国土美化よりもさらに積
極的な計画・開発への言明への接続といえる。さらに農業を単独と してではなく産業（工業）をそこに挿入することにより改革しよう とする点に関してエマソンとライトとの大きな差異が見出される。

Agrarianism holding its own; agronomy as cultural education for industrialism proceeds. Both could and would be cooperative. But as it now is, industrialism as producer is no fair partner for agronomy.

[LC:155]

農耕主義は、本来の姿を保つ一産業主義が進歩するための、文 化教育としての農耕、工業と農業はお互いに協力し合えるもので あり、また協力し合うものである。しかし、現在のように工業が 生産者としてあるのは、農業にとって公正なパートナーではある まい。

このように、ライトは農業および農夫をエマソンと同様に原則とし て肯定的に評価してはいるものの、当時の農業や農夫の置かれてい る位置が、“最も野卑で最も毒々しい形の賃貸に煩わされている (rent in its rankest, most virulent form)" [LC:158]と指摘し、彼らの 生活を不衛生なものと紏弾する。こうした認識からライトは理想都 市ブロードェーカー・シティを提案し、そこに有機的建築を建てよ うとするのである。それはライトの農夫に関する以下のような言明 にみることができる。

He will need the kind of buildings now that will end unceasing tramping in mud or snow in and around about the ill-smelling inefficient group of ill-adapted buildings that had become a habit to him and a disgrace to his country. [LC:161]

彼にとっては慣習となり、彼の国家にとっては不名誉なものと なっている、不似合いな建物の非効率的な群れの悪臭漂うなかを、 休むことなくちょうど泥濘か雪中を歩むように彷得っている状態 に終止符を打つような建物が彼には必要なのである。

こうしたライトの農業思想は、エマソンの思想に多大な影響を受け つつも、建築・都市としての提案においては自身の創作意図を前面 に押し出し、思想的文脈に沿って評価したものといえるる ${ }^{28)}$ 。両者 ともそれぞれが生きた当時の都市生活に対し懐疑的姿勢をとりなが らも、エマソンは農村・農夫を、精神性・道徳性の高いものとして 主張し、ライトは自身が描く理想都市に農業を組み入れ、産業との 合一を主張した点にその差異性が認められる。このことからも、ラ イトはエマソンの思想を部分的に援用・咀嚼したうえで、具体的な 建築・都市像として提案したものと指摘できる。

\section{7.おわりに}

ライトの『リヴィング・シティ』に引用されたエマソンの随筆「農 業」を手掛かりとして、ライトの言説にみられる農業思想とエマソ ンのそれとの比較分析・考察を行うことで、ライトに対するエマソ ンの影響内容および程度を考定した。その結果を以下のように総括 できる。

(1)ライトは自然や有機といった超越主義に総じてみられる基本概念 を共有しつつ29)、エマソンの言説にみられる農業思想から大きな 影響を受け、自身の都市論を展開している。そこでは自然への近接 が尊げれ、さらに重要概念である “ユーソニア”に直結させられて いる点に特質が認められる。

(2)両者の農業思想にみられる相同性として、真正・健全な職能とし 
ての農業と、それへの従事により自己修養・訓練を積んだ農夫を高 く評価する点が挙げられる。そこには、随筆引用のみに留まらない ライトとエマソン双方の農業思想を介した高い類似性が認められる ことからも、強い影響関係が窥われる。

(3)ライトの農業思想がエマソンのそれとの差異を見せるのは、エマ ソンが強調した国土の美化効用についてである。ライトはエマソン の農業思想を咀嚼しながらも、農業が国土を美化するという効用に 加え、さらに独自の着眼点として現状の農業を危機的状況として捉 え、そうした状況を超える理想都市では農業と産業の一体化した社 会が構築されているとしている30)。このことからも、『リヴィング ・シティ』においてエマソン的な農業思想は重要な位置を占めなが らも、その思想への全面的な信奉・援用ではなく、新たな視点・主 張を多分に加味したものであったことも併せて指摘できる。

(4)ライトが『リヴィング・シティ』巻末においてェマソンの随筆「農 業」を引用したことの意味は、まさにライトが農業を主軸とする都 市論を唱導するに際して、アメリカ思想の泰斗と目され、自身も敬 愛したエマソンの言説を引用することにより、いわば自説を権威付 けすることを企図したものと推察できる ${ }^{31}$ 。

以上のような農業思想を主軸としたライトの都市計画思想につい て、従来はジェファーソンに由来する農本主義の流れを汲むものと して捉える見方があったが、彼からの影響を示す形跡をライト自身 の言及から明確に見出すことはできない。その証左として、ライト の著作集にみられるジェファーソンの言及には貴族主義や民主主 義、個人主義に関連してなされるものの、農業思想と結びつけての 言及は一切みられない。このことからも、ライトの都市論にみられ る農業思想には、むしろエマソンにその淵源を求めることができよ $う^{32 !}$ 。

今後の課題として、第一に、本稿でみた『リヴィング・シティ』 以外のライトの言説へと対象を広げて言説収集・分析を行うととも に、「有機的」、「自然」といった上位概念をも含めた総合的見地よ りライトへのエマソンをはじめとする超越主義思想の影響を明らか にすること ${ }^{33}$ 、第二に、ここでみた影響関係は、実際にはライト の実作品や計画案、彼自身の生活態度といった側面での思考・実践 と同時並行的に展開されたものであり、それらの間には極めて強い 相互関連性があることも指摘できうるため、これら領域をも含めた 比較考察を通じ、超越主義が及ぼしたライトの都市論に対する影響 の全体像を考究していくこと、を挙げておきたい。

\section{註および参考文献}

1) Frank Lloyd Wright (1958) The Living City, Horizon Press（邦訳は谷川正己、 谷川睦子訳 (1968)『ライトの都市論』, 彰国社)。

2) 同前, pp.223-224。

3) F.L.Wright (1932) The Disappearing City, William Farquhar Payson.

4) F.L.Wright (1945) When Democracy Builds, revised ed., University of Chicago Press（邦訳は二見甚郷訳 (1949）『デモクラシイの真蹎』，永晃社)。ライ トは本書のエピグラフとして超越主義者ウォルト・ホイットマンの詩編を 引用しているが、『リヴィング・シティ』においては削除され、それに代 わり神学者 P.A.パラケルスス (Philippus Aureolus Paracelsus:1493-1541)の文 章が引用されている。なお『民主主義建設の時』出版後すぐ若干の加筆訂 正を伴い同名の改訂版が出版されているが、本稿では水上論文（註 8 p.218）と同様、改訂の詳細には踏み込まない。

5）都市関連 3 著作からの引用に際して、出典表記を『リヴィング・シティ』 を[LC]、『民主主義建設の時』を[WDB]、『消えゆく都市』を[DC]、あわ せてエマソン(1968) The Complete Works of Ralph Waldo Emerson, Vols.12, AMS Press を[CWE] と略記し、各々該当する巻数ならびに頁数を示した。 筆者による中略は・・・で示した。なお引用文は邦訳を随時参考としたが、 筆者らの文脈に照らし合わせ訳を一部改めている。

6) Anthony Alofsin (1989) Broadacre City: The Reception of a Modernist Vision, 1932-1988, Center: A Journal for Architecture in America 5, Rizzoli。

7) Robert Fishman (1987) Bourgeois Utopias, Basic Books Inc。

8）水上優 (2004)「F.L.ライトの都市思想における『ブロードェーカー・シ ティ』のフォーム」, 日本建築学会計画系論文集, No.58i，pp.211-218。エ マソンの影響については註に扔いて簡単に言及している。

9）ウィリアム・クロノン(1995)「不安定な統一：フランク・ロイド・ライ トの情熱」，所収；T.ライリー，P.リード編『建築家：フランク・ロイド ・ライト』(京都大学内井研究室監訳), デルファイ研究所, pp.10-33。

10）水上優 (2006)「超越主義 3 詩人の思想の基底とライトの建築思想」, 日 本建築学会近畿支部研究報告集，No.46，pp.837-840、および同(2006）「超 越主義 3 詩人の思想の差異とライトの建築思想」，日本建築学会大会学術 講演梗概集 F2 分冊, pp.479-480。

11) Naomi, Uechi (2000) Emersonian Transcendentalism in Frank Lloyd Wright's Unity Temple, ISLE: interdisciplinary studies in literature and environment, No.7, University of Nevada, pp.95-113。

12）大倉将裕、鈴木一(1987)「ラルフ・W・エマソンの造形思想について」, 日本建築学会関東支部研究報告集, pp.305-308。

13) Giorgio Cuicci (1983) The City in Agrarian Ideology and Frank Lloyd Wright Origins and Development of Broadacres, The American City From the Civil War to the New Deal, MIT Press, pp.293-387。冒頭にエマソンの言葉「町よりも 人間が優れているわけではなかろうか(Is not a man better than a town)」が 引用されている(p.293)。

14）ライトの都市論に対するジェファーソンの影響については次の指摘がみ られる。M.タフーリ，F.ダル・コは「アメリカ文化の創設者の哲学一ソロ 一の個人主義、ジェファーソンやエマソンの自然主義一に戻ることは、「有 機的建築」を「有機的社会」と同一視することを意味し、「自然」と交感 できる個人一18世紀的方法による一つの抽象とみなされる一だけが、自ら のコミュニティを築くことができるという個人の完全性を賞揚することを 意味していた。と指摘し、ライトの思想への影響はエマソンとジェファ ーソンが自然主義を介し併記される。(『近代建築』(片木篤訳)，本の友社， p.80)。L.ライスマンはライトの思想に清教徒的でジェファーソン的な性 格がみられることを指摘している(ライスマン(1964)『新しい都市の理論』 (星野郁美訳)，鹿島出版会，p.60)。またT.ライナーはライトの思想を、 ジェファーソン流の簡潔な環境の中で、蕨しい個人主義と創造力を育成す るものと評している。(1967)『理想都市と都市計画』(太田実研究室訳), 日本評論社, pp.77-79 参照。

15）言説の収集にあたってはライトの著作選集を対象に、そこにみられる人 物言及䇢所を収集した。F.L.Wright (1992-1995) The Collected Writings of Frank Lloyd Wright, edited by B.B.Pfeiffer, 5 volumes, Rizzoli。

16）人物言及については竹内孝治・小川英明 (2006)「F.L.ライトの言説に みられる超越主義者の言及に関する考察」, 日本建築学会大会学術講演梗 概集F-2 分冊, pp.237-238 を参照されたい。 
17) 同前, p. 238 。

18）テニスンの詩編引用については星谷俊朗 (2006) 「フランク・ロイド・ラ イトの"A TESTAMENT" (遺言)のエピグラフについて」, 日本建築学会大会 学術講演梗概集 F-2 分冊, pp.481-482 を参照。ブレイクの引用は前掲書 The Collected Writings of Frank Lloyd Wright, Vol.5, p.157。

19) R.W.Emerson (1870) Society and Solitude: twelve chapters, Mifflin Houghton に収録。本稿では[RWE7:135-154]を参照した。初出は 1858 年のミドルセ ックス農業組合における講演である。本稿では発表年を最終的に収録され た単行本の出版年とした。初出は講演であるものの、エマソンが自著を講 演録としては意図せず独立した著作として出版したことからも、出版年次 時点における思想表明とみなせるものと判断したためである。

20）こうした科学主義的な志向性は18世紀後半から19世紀前半までのアメリ カにみられる。禹津浩子(2005)「進化」する自然誌 初期エマソンをめぐ って」,『時の娘たち』所收, 南雲堂, pp.213-230を参照。

21）酒本によれば、エマソン思想の特質は特に「自己信頼(self-reliance)」と いう概念にみられる（酒本雅之 (1974)『アメリカ・ルネッサンスの作家た ち』, 岩波書店, pp.76-77。その他、同 (1969)『アメリカ・ルネッサンス序 説』, 研究社を参照)。農夫にみられる自給自足の生活姿勢は、この「自己 信頼」の思想に極めてよく馿染むものであり、また超越主義に総じてみら れる自然との親和性においても格好のモデルとされたことが予想される。 このようなエマソン思想の全体像と、本稿で考察する農業思想、さらには、 それらがライトの思想といかなる对応関係を持つかに関しては、次報以降 において检討したい。

22）[RWE1-12]。なお引用文は随時以下の邦訳を参照しつつ、文脈に沿い改 变した。梁藤光まか訳 (1961) 『エマソン選集』(全 7 巻)，日本教文社、お よび平田秀木訳 (1917)『エマアソン全集』(全 8 巻), 國民文庫刊行會、酒 本雅之訳 (1973)『エマソン論文集』(全 2 巻)，岩波書店。

23）農業に関連する語句としては、以下のものを抽出した。farm、farmer、 farming、farmstead、farmster、farmerettes、agriculture、agrarian、agronomic、 agronomy 、tiller of soil、 tillers of the fields

24）言説分析に際しての主題抽出は、広義の意味において K J 法に準抛する が、元来、KJ 法はブレーンストーミングを中心に、新たな発想を促す情 報処理のための一連の作業行程を指す。本論文では言及される主題別に類 似する内容を整理し、そのグループごとに論述内容を考察するという作業 手順を採るが、これは $\mathrm{K} \mathrm{J}$ 法の行程における初期段階に該当する（川喜田 二郎 (1967)『発想法』, 中央公論社を参照)。なお、「主題」の定義には多 様な解积がありうるが、ここでは、言及される話題の整理・分類により「主 たる話題」を導出したという経緯においてのみ「主題」と表記する。これ は以下に述べる方法的態度に基づくものである。つまり、本論文は従来の 諸論評による影響指摘の妥当性を再考することをも視野に入れ考察するた めに、思想的な連関性および諸論評に基づく先入見を予め排除した上で、 ライトおよびエマソン自身の「農業関連啰説」のみに止まり、その限りに おいて両者の親近性を見極めるという姿勢である。換言するならば、各人 の思想がもつ全体像から農業思想を析出するのではなく、農業関連言説に みられる価值判断構造への考察から、さらにその上位概念へと遡及してい く方法である。ゆえに、本論文で得る成果は最終的なものではなく、ここ で得た知見をもとに、今後さらに上位概念の分析を必要とする。

25）ライト、エマソン共に、その農業思想は各主題が相互に連関しつつ成立 しており、個別の主題として明確に線引きできるものではなく、同一言説 が複数主題に重複して分類される場合もある。
26）マイケル・T、ギルモアは、エマソンの農業観が随筆「農業」において変 容したことに触れている(ギルモア (1995)『アメリカのロマン派文学と市 場社会』(片山厚, 宮下雅年訳), 松柏社, pp.46-48)。農業への賛辞に変化 はないものの、農夫が紡績工場の番人に例えられることから、“このとき 描かれる自然は、流動的に姿を変える自然ではなく、「巨大な機械（中略） しかも狂ったためしのない」機械なのである。農民が工員にたとえられる とすれば、もはや独立独行の鑑とはほとんど考えられない”と指摘してい る。ギルモアの議論については検討を要するが、これを鑑みるならば、ラ イトが上記「紡績工場の番人」という文章を中略し引用した背景に、エマ ソンの農業理解にみられる変容との関連性が予想される。

27）ライトは『リヴィング・シティ』において、4つの鍵概念、「有機的 (Organic)」「分散化 (Decentralization)」「統合 (Integration)」「民主主義 (Democracy)」を掲げている(LC:218)。こうしたライトの都市思想につい て水上は、「〈自然一人間〉関係の問い直し」を志向し、「自然なる全体に 統合されている」ことを「根本的形式」とするものと指摘している（前揭， 水上 (2004), p.217)。このことからも、農業という職能・業態がもつ特質 が、「有機的」に「自然なる全体性」において「統合」される契機あるい はモデルとして位置づけられていると予想される。ライトの農業思想が「有 機的」、「民主主義」等の概念を鍵としたライト思想の全体において持つ位 置づけは、今後、本稿の成果に基づき検討を予定している。

28）ライト、エマソン双方の農業に関する各主題の間にみられる照忍関係は、 ここでみた以外にも、複雑に対応していることが読み取られる。

29）ライトに対する超越主義の影響を指摘する諸研究では、前掲のクロノン を代表として、そのほとんどが “自然”、“有機”等を鍵概念として超越主 義の思想・理念を継承したとしている。註26で述べたと同様、これら概念 に着目し、さらにライト、エマソン双方の思想比較を行いたい。

30）農業と工業との並置は、ピョートル・クロポトキンの著書『工場、農場、 仕事場 (Fields, Factories and Workshops)』（1898）にみられる小自作農、小工 業経済の現代版として捉えられることが指摘される（ケネス・フランプト ン(2003)『現代建築史』(中村敏男訳), 青土社, p.334)。その他ヘンリー ・フォードの思想を解釈・提案したものとしても評価される（ジャン＝ル イ・コーエン (1998)「近代の都市計画とメトロポリスの危機」，所収：『建 築の20世紀』(鈴木博之監訳)，デルファイ研究所, p.250)。

31）あるいは自身の農業思想の源泉にエマソンを率直に挙げつつも、ライト は自らがェマソンらの真正なアメリカ文化思想家の正統的継承者であり、 かつそれを具体的な都市提案を行う創造力においてエマソンを越えること を表明したと仮説付ける可能性も指摘できる。

32）ジェファーソンの農業言説として知られるものに、『ヴァージニア覚え 書』の「大地に㗢く人々こそ神の選民であって、神はこれらの人々の胸を、 根源的で純粋な徳のための特別な寄託所として選んだのである」といった 一連の言説があるが（中屋健一訳，岩波書店，1972，p.297）、そこでは農 夫の精神性・道徳性に触れるのみであることからも、ライトとの親近性は エマソンの方がより強いといえる。その他にも以下を参照。ソール・K. パドーヴァー編 (1961)『ジェファンンの民主主義思想』(富田虎男訳), 有 信堂, pp.77-80。A.ホイットニー・グリスウォード(1952)『農村と民主主 義』(篠原泰三ほか訳)，東洋経済新報社，pp.16-47。

33）ライトの農業関連言説は、都市関連 3 著作以外にも例えば Frank Lloyd Wright (1937) Architecture and Modern Life, Harper \& Brothers Publishers で多 くみられる。ライトとェマソンそれぞれの農業思想を対象に比較考察をさ らに梁いものとするには、これら言説をも含めた考察が課題といえる。 